\title{
Does More Corporate Governance Enhance Managerial Performance? CFO Perceptions And The Role Of Mindfulness
}

\author{
John J. Williams, Singapore Management University, Singapore \\ Alfred E. Seaman, Humber Institute of Technology \& Advanced Learning, Canada
}

\begin{abstract}
The results of studies into the effects of enhanced governance structures have been equivocal and there is virtually no literature on the performance effects of individual managers, such as the professional accountant in practice. This paper reports the results of an empirical study designed to assess the relationship of governance structures, specifically the conformance and performance dimensions defined by the International Federation of Accountants (2009), to mindfulness and managerial performance among CFOs in Canadian firms. Organizational theory describing high reliability organizations provides the theoretical framework for specifying and appraising capacity for mindfulness. As predicted, there is no significant direct relationship between governance and managerial performance for the conformance dimension; instead, this relationship is explained by the path through capacity for mindfulness and on to managerial performance, both of which are positively significant. Likewise, there is no significant relationship between governance and managerial performance for the conformance dimension; however, although there is a significant path between the performance dimension and capacity for mindfulness, the path from the latter to managerial performance is insignificant. Implicating the powerful role of the controllability principle in accounting may explain this unexpected finding.
\end{abstract}

Keywords: Corporate Governance; Managerial Performance; Mindfulness; Path Analysis

\section{INTRODUCTION}

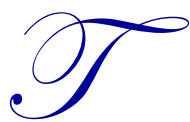

he simple two page 'best practice' guidelines of the Cadbury Report (1992) ${ }^{1}$ spawned a massive interdisciplinary literature on corporate governance (CG) around the globe, with inextricable ties to accounting in particular. Accounting is implicated because it creates the structural systems and routines necessary to provide information required for most governance mechanisms to operate efficiently in the firm, including roles of the audit committee, various stakeholders, and the board of directors (Sloan, 1992; Bushman \& Smith, 2001). With surprising swiftness, the legacy of the Cadbury Report spread not only to institutions and countries $^{2}$ but gave rise to a normative practice literature in accounting featuring the role of the professional accountant in business (e.g., International Federation of Accountants, 2008, 2009; PricewaterhouseCoopers, 2008), including the CFO operating at the pinnacle of the firm's accounting hierarchy (Segal, 2002; Henman, 2013). The conventional wisdom, generally speaking, is that adherence to these codes of best practice through better or improved CG mechanisms should lead to better corporate performance.

Recent reviews of the governance research literature (Shleifer \& Vishny, 1997; Bushman \& Smith, 2001; Ahrens, Filatotchev, \& Thomsen, 2009; Durisin \& Puzone, 2009; Brown, Beekes, \& Verhoeven, 2011) highlight

\footnotetext{
${ }^{1}$ Although the Code of Best Practice was succinct and clearly articulated, making it remarkably appealing in the corporate governance literature around the world (Jordan, 2012), variations have emerged over time and definitions of corporate governance are potentially problematic (see Scott, 1999 for example).

${ }^{2}$ See for example the OECD Report (Business Sector Advisory Group on Corporate Governance, 1998) and the UK Corporate Governance Code (Financial Reporting Council, 2010).
} 
studies on accounting outcomes, such as disclosures (Beekes \& Brown, 2006), analysts' earnings forecasts (Byard, Li, \& Weintrop, 2006), conservatism and earnings timeliness (Watts, 2003), earnings informativeness (Ahmen, Hossain, \& Adams, 2006), and earnings management (Kim \& Yi, 2006, 2009), to name a few. Disappointingly, this enormous ambit of governance research has led to no better understanding of consistent economic firm performance (Brown et al., 2011) in addition to failure in uncovering universal constants in the CG/performance relationship (Ahrens et al., 2009).

Surprisingly as well, these reviews, and the literature at large, are silent on the issue of the effect of CG on managerial behavior, notably the performance of the accountant in practice. As Ahrens et al. (2009, p. 320) contend "Practical understandings cannot therefore arise from principles or rules in isolation, nor can they be imposed by regulators," thus implying some intervening effect between governance structures and processes in the firm, and the inescapable need to evaluate individual performance. This suggested nomological network involving an intervening variable exactly mirrors a central tenet of structural organization theory (Burns \& Stalker, 1961; Lawrence \& Lorsch, 1967; Perrow, 1970; Galbraith, 1973) which posits that focal variables (CG and outcome criteria) are not directly related. Put differently, there is no theoretical argument which can support simple, direct effects of governance routines and related activities on performance outcomes. Rather, the effects of governance processes, if any, are indirect and are probably manifest in outcome criteria via some intervening cognitive variable which links them. Hence, this perspective is labeled the 'intervening variable model'. Ultimately, of course, firm performance is thought to be enhanced by optimizing the performance outcomes of individuals in goal attainment. ${ }^{3}$

This paper reports the findings of an empirical investigation of the effects of mindfulness on the relationship between CG and managerial effectiveness, within the framework of the intervening variable model. Capacity for mindfulness was chosen as the intervening variable on the basis of the theoretical arguments linking $\mathrm{CG}$ to it, and in turn, predicting its effect on managerial performance. Regression results from a recent study by Williams and Seaman (2010) revealed that both the conformance and performance dimensions of CG are significant determinants of the capacity for mindfulness: however, managerial performance was not addressed.

Evidence presented here, based on perceptions from a sample of Canadian CFOs, shows strong positive zero-order effects of CG on capacity for mindfulness for both dimensions of CG, but similarly strong positive direct effects from capacity for mindfulness to managerial performance only hold for the conformance dimension and not the performance dimension of CG (see Figures I and II). Moreover, all direct effects from CG to managerial performance are insignificant, suggesting the shortcomings of a simple bivariate approach to exploring the links between CG and managerial outcomes, and supporting instead the central tenet of no direct effects as predicted in structural organization theory. Since virtually all codes of good practice for accountants are aimed at creating a balance between performance and conformance structures in CG, the results of this study suggest that this initiative needs to be re-addressed.

The remainder of the paper is organized in the following manner. The next section reviews the professional literature on CG and develops the linkage of an intervening path model involving mindfulness in the relationship between CG and managerial performance. This discussion forms the basis for identifying the research hypotheses. Next, a method section addresses the sample, measurement of variables, and the path analytic framework followed by the results section. A brief discussion of the findings, potential limitations, and suggestions for further research close out the final section.

\section{BACKGROUND, THEORY DEVELOPMENT, AND HYPOTHESES}

In 1992, the Cadbury Report (para. 2.5) stated that "Corporate governance is the system by which companies are directed and controlled." A plethora of definitions and prescriptions by various institutions around the globe followed, with the central notion being that CG is embedded in a framework of rules, procedures, activities, practices, or mechanisms - features that this paper refers to as a set of 'routines'. Approximately a decade

\footnotetext{
${ }^{3}$ It seems reasonable to assume that the intent of CG guidelines on "best practices" is to encourage managers to adapt to changes in contingencies in order to attain fit and enhanced performance, not just organizational but at the individual level as well. Tymon, Strout, Jr., and Shaw (1998, p. 25) explain this process cogently in terms of four quadrants beginning with the strategic perceptions of top managers, design of the organization's structure and control systems, impact on individual motivation and performance and, ultimately, to organizational effectiveness.
} 
later, the salient feature to emerge in various CG codes of best practice was the idea of a balanced perspective involving two dimensions (IFAC, 2004, 2005; Tessier \& Otley, 2012); a more proactive forward-looking performance dimension and a conformance dimension which tends to take a historic view. The IFAC $(2009$, p. 8$)$ is exemplary in this respect and posits that these two dimensions "together represent the entire value creation, resource utilization, and accountability framework of an organization." Specifically, conformance centers on three types of routines that deal with accountability, assurance, and risk oversight while the performance dimension focuses on three types of routines encompassing strategy implementation and evaluation, mapping resources to strategies, and value creation.

The major premise underpinning the governance framework is that carefully crafted routines and behavior that enhance these two dimensions "... can lead to better outcomes and increased stakeholder value across all entities" (IFAC, 2009, p. 5). None of these prescriptions, however, privilege attention to individual behavior associated with CG routines that, in essence, make them function. Fittingly, recent literature calls for more studies that address key relationships between corporate governance practitioners (Ahrens et al., 2011) and that give attention to behavioral dynamics among actors and settings involved in governance phenomena (Huse, Hoskisson, Zattoni, \& Viganò, 2011; McNulty, Zattoni, \& Douglas, 2013).

However, the notion that enhanced CG routines directly lead to improved managerial outcomes is reminiscent of early universalistic theories in accounting research studies that investigated the direct effects of various management accounting system attributes (routines) on the criterion variable (performance). For example, Merchant (1981) documents the failed attempts of most studies (e.g., Milani, 1975; Steers, 1976) to find simple, bivariate relationships between uses of budgeting and managerial performance. Other unsuccessful efforts and contradictory findings dealing with budgetary participation and performance are highlighted by Govindarajan (1986). Hopwood (1976, p. 79) endorsed a contingency approach to examine these relationships and sealed the fate of a universalistic approach by stating the need "to identify which conditional factors determine the wider impact of a particular type of ... management program." Hence, the general inference from structural contingency theory and related research is that a positive direct linkage from a structural variable (i.e., CG) to performance outcomes is unlikely (Daft, 1983). Instead, any increase in performance is anticipated to materialize via the intervening path from CG through the capacity for mindfulness in the present study. In summary, the model depicted in Figure I and Figure II, respectively, leads to the following hypotheses:

H1a: There is no significant direct relationship between the conformance dimension of CG and managerial performance.

H1b: There is no significant direct relationship between the performance dimension of CG and managerial performance.

\section{Capacity for Mindfulness as an Intervening Variable}

Calls for more, better, or improved CG routines appear to be highly correlated with increases in environmental risks and/or corporate failures generally. The argument is usually framed in terms of organizations needing to become more successful (IFAC, 2004, 2008, 2009; PricewaterhouseCoopers, 2008, 2012). Equally valid, though, is the inverted argument that adhering to better governance principles serves to circumvent failure and avoid threats, thereby yielding more reliable systems. This latter interpretation coincides closely with the perspective of organization theorists who study 'high reliability organizations' (HROs) but they treat reliability, and hence effectiveness, in a very distinctive and unique manner. Instead of assuming repeatability and invariance in operating procedures, the focus shifts to "... the reality that reliable systems often must perform the same way even though their working conditions fluctuate and are not always known in advance" (Weick, Sutcliffe, \& Obstfeld, 1999, p. 86). Thus, routines cannot deal with what was not planned and, therefore, they must become variable in the face of uncertainty. So HROs manifest "... variation in activity, but there is stability in the cognitive processes that make sense of this activity" (Weick et al., 1999, p. 87).

To understand this bifurcation more fully, it is useful to contrast organizations focused on efficiency versus those that enact high reliability. Starbuck, Greve, and Hedberg (1978) suggested that efficient organizations tend to do the same activities even in the face of changing conditions. For various reasons, people are hurried, distracted, 
careless, or simply unaware that events are changing and, therefore, create errors that go undetected. Perrin (1995, p. 156) argued that from a reliability perspective it is precisely these circumstances which "... require revision of situation assessment and plans ..." and this can only be accomplished if individuals "... revise their understanding of the situation, their evidence collection and evaluation tactics, or their response strategy...." Weick et al. (1999) contended that reliable outcomes are thus brought about by subjecting varying processes of production to stable processes of cognition. Simply put, "These stable cognitive processes do the detecting, the variable patterns of activity do the adapting to events which require revision" (p. 87, emphasis added). This same pattern appears to be endorsed by normative prescriptions in the quest for improved governance practices (IFAC, 2009, p. 5): "As organizations and their environments change, the governance system must adapt to future opportunities and threats by improving processes and practices" (emphasis added), except that cognitive processes are missing from these accounts.

Langer $(1989,1997)$ labeled the ability of a diverse set of cognitive processes to uncover a 'rich awareness' of differential detail combined with a 'repertoire for potential action' as mindfulness. Rochlin (1989, 1993) developed the view that it is this enhanced awareness in individuals that fuels the discovery and correction of errors or unexpected events that can harm or cause the operating system to fail. Weick et al. (1999, p. 90) build on this thinking and the work of Westrum (1992): "Thus, the richness of a state of mindfulness is determined by the richness of the action repertoire. The richness of that action repertoire, in turn, is determined partly by the extent to which the cognitive processes are stable and continue to develop and partly by the extent to which the repertoire of variable routines that uncover and manage unexpected events continues to expand." By extension then, increases in the platform of governance routines called for in 'codes of best practice' should enhance the capacity for mindfulness in managers involved in the operations of the organization.

The linkage of mindfulness and managerial performance can be understood by underscoring the continuous processes found in HROs that contribute to failure avoidance, the detection of errors, and the suppression of inertia since these "provide the cognitive infrastructure that enables simultaneous adaptive learning and reliable performance" (Weick et al., 1999, p. 82). First, successful HROs harbor a preoccupation with failure which applauds the reporting of errors (Tamiz, 1994); treats near misses as threats (March, Sproull, \& Tamuz, 1991); and sanctions complacency, risk aversion, and inertia (Sitkin, 1992). Second, there is reluctance to simply and, instead, a drive to: cultivate requisite variety (Perrin, 1995); increase complexity (Schulman, 1993); and nurture interpersonal skills and mutual respect (Weick, 1993; Bierly \& Spender, 1995). Third, Weick et al. (1999, p. 98) cite Roth's (1997) work on sensitivity to operations which involves “... shared mental representations ..., situation assessing with continual updates ..., and active diagnosis of the limitations of preplanned procedures." A fourth process is resilience which refers to the "capacity to cope with unanticipated dangers after they have become manifest" (Wildavsky, 1991, p. 77) while a fifth process deals with unloosening the authority structure to match problems with needed expertise when there are 'never seen before' surprises (Weick, 1990).

In the setting of professional accountants in practice, mindfulness is expected to enhance the extent to which they understand their duties and responsibilities, including planning, coordinating activities, assessing and managing risk, interpreting and reporting required information, providing internal control, utilizing resources effectively, and generally reducing errors and failure in the system to ensure "effective and efficient practices" (IFAC, 2009, p. 6). Not fulfilling these objectives is certainly not as catastrophic a consequence as, say, a nuclear disaster in the world of HROs; however, to the professional accountant who expects not to fail and has undertaken precautions to prevent errors, these outcomes can be ruinous and career challenging. As Weick et al. (1999, p. 106) so nicely phrase undesirable consequences: "To put catastrophes on the same scale as one's tasks is to see the potential for big trouble arising from small moments when intentions fail, when a surprise occurs, or when a near miss and good luck reveal unexpected danger."

Evidence in the literature linking CG and capacity for mindfulness is extremely limited. In an exploratory study, Williams and Seaman (2010) presented regression results supporting the hypothesis that both the conformance and performance dimensions of CG are significant determinants of the capacity for mindfulness. Moreover, the explanatory power of this relationship rises significantly when the change in management accounting systems is enlarged. Together, this supporting evidence and the theoretical arguments presented above form the basis of an expectation that CG will be positively related to capacity for mindfulness. Unfortunately, there is no 
available empirical evidence in the literature on the linkage between the capacity for mindfulness and managerial performance; nonetheless, there is the expectation that the relationship is positive based on the above discussion of cognitive processes. In terms of Figures I and 1I, the following hypotheses emerge:

H2a: The simple relationship between the conformance dimension of CG and managerial performance will be explained by an indirect effect whereby CG increases the capacity for mindfulness, this in turn enhancing managerial performance.

H2b: The simple relationship between the performance dimension of CG and managerial performance will be explained by an indirect effect whereby CG increases the capacity for mindfulness, this in turn enhancing managerial performance.

\section{METHOD}

\section{Sample Selection and Data Collection}

The data collection involved a survey questionnaire directed at CFOs/controllers of Canadian companies. All companies had more than 200 employees, and this filter provided some degree of control over the size of the firms in the sample. The CFOs/controllers were randomly chosen from the directory of the Society of Management Accountants of Canada. The survey instrument was web-based and part of a larger, ongoing research project involving Canadian-based companies. Respondents were cross-referenced to the Society's registry to confirm active membership and designation. The entire questionnaire was pilot-tested successfully to assess its length, understandability, and general attractiveness, as well as to ensure maximum reliability and validity of all measurement scales. ${ }^{4}$

Nearly 900 responses were received but they were subjected to several filters. As mentioned above, firms with less than 200 employees were eliminated since their governance structures may not reflect those of larger companies. Also, a tenure requirement of four years was invoked so as to ensure some degree of experience, expertise, and responsibility in the role of leading the accounting function in the firm. Finally, utility and non-profit organizations were excluded for reasons of non-homogeneity following other management accounting research studies (e.g., Chenhall \& Brownell, 1988; Brownell \& Dunk, 1991). These filters reduced the sample to 154 usable responses, from which 23 were incomplete and 6 indicated no variance, leaving a usable sample of 125 firms. Following Armstrong and Overton (1977), the sample was split into two groups of approximately equal size based on date of response to compare differences in the means and standard deviations of the measured variables. This procedure yielded no evidence of response bias.

\section{Measures}

\section{Corporate Governance}

The performance and conformance dimensions of CG were measured by three scales each which were originally developed by Williams and Seaman (2010) and that map the guidelines published by the IFAC (2009). The performance measure included 'strategy', 'communication', and 'value creation' which are intended to reflect the accountant's role in the core processes overarching strategy implementation and evaluation, value creation, and the alignment of business operations and resource utilization as specified by the IFAC (2009). Three scales covering 'accountability in the reporting function', providing 'assurances of ethical conduct and managing conflicts of interest', and the 'effectiveness of risk oversight' were developed to capture the conformance dimension of CG in the tenor expressed by the IFAC (2009). Items within all six scales were rated on a fully anchored Likert scale ranging from 1 (to a very little extent) to 5 (to a very great extent) and an average score was calculated for each scale.

For the performance dimension, the strategy variable was formed from a three-item scale that yielded a single factor and explained 86 percent of the total variance. The communication variable was likewise determined

\footnotetext{
${ }^{4}$ For further details on the larger study and the pilot test see Williams and Seaman (2010, p. 5).
} 
by a three-item scale that yielded one factor accounting for 75 percent of the total variance. A three-item scale was used to measure the value creation variable which produced one factor explaining 71 percent of the total variance. Eigenvalues of $2.55,2.21$, and 2.15 from the respective factor analyses confirmed the single-factor structure of each scale. Reliability coefficients of $0.91,0.81$, and 0.79 emerged for each scale, respectively, using Cronbach's (1951) alpha statistic and they are well within Nunnally's (1967) inter-item reliability standard. Thus, the performance dimension of corporate governance variable, PDGC, constituted these three measures as inputs to the structural equation model (SEM) utilized in this study.

Turning to the conformance dimension, three items measured the accountability variable while two-item scales were used to measure the variables assurance and risk, respectively. Factor analyses of these scales rendered single-factor structures with eigenvalues of 2.18, 1.92, and 1.87, which explained 73 percent, 95 percent, and 92 percent of the total variance, respectively. Alpha coefficients of $0.81,0.96$, and 0.92 , respectively, revealed very strong inter-item reliability for all three scales. Hence, the conformance dimension of corporate governance variable, CDCG, consisted of these three measures as inputs to the SEM.

\section{Mindfulness}

Capacity for mindfulness was measured using five scales initially developed by Weick and Sutcliffe (2001) and tested successfully by Williams and Seaman (2010). Items for all scales were rated on a fully anchored Likert scale ranging from 1(to a very little extent) to 5 (to a very great extent). Four-item scales were used to measure 'preoccupation with failure,' 'sensitivity to operations,' and 'deference to expertis,' each yielding one factor with eigenvalues of $2.17,2.70$, and 2.08 , respectively. Three-item scales were used to measure 'reluctance to simplify' and 'commitment to resilience' which produced single-item structures having eigenvalues of 2.22, and 2.03, respectively. The variance from the factor analysis for each of the five scales ranged from 63 percent to 74 percent. Observed alpha coefficients were $0.67,0.76,0.82,0.82$, and 0.78 , respectively, suggesting strong internal reliability. An average score was then determined for each of the five mindfulness scales. These five measures were used as inputs to the SEM to represent the CMIND variable.

\section{Managerial Performance}

The performance measure developed by Mahoney, Jerdee, and Carrol (1963, 1965), and initially introduced to the managerial accounting literature by Brownell and McInnes (1986), was employed in the study. It asks for ratings on a Likert scale ranging from 1 (to a very little extent) to 5 (to a very great extent) for each of eight items of performance, namely, planning, investigating, coordinating, evaluating, supervising, staffing, negotiating, and representing. In addition, the original Mahoney et al. (1963) scale asks for a single overall rating, to be used when different managerial functions (i.e., sales and manufacturing) are being assessed because they feature different mixes of the eight dimensions. This instrument has been used successfully in a variety of managerial accounting studies (Chong \& Chong, 2002; Hall, 2008; Otley \& Pollanen, 2000; Parker \& Kyj, 2006). A majority of the studies use the single overall rating because of the non-uniformity of the managerial functions in any given study. However, the richness of eight dimensions versus a single dimension is not in dispute (Mahoney et al., 1963, 1965) provided that multi-collinearity is not an issue. Given that the managerial function of CFOs in the present study was considered to be relatively homogeneous considering the firms sampled, the eight items were used as inputs to the SEM to measure the MPERF construct. To further reinforce this approach, correlations among the eight dimensions were analyzed and no strong correlations existed, suggesting that independence among them was not violated (Mahoney et al., 1963). ${ }^{5}$

\section{Analysis}

To investigate the intervening effect of mindfulness on the CG/performance relationship, the conformance and performance dimensions of CG were handled separately as modeled in Figures I and II, respectively, using

\footnotetext{
${ }^{5}$ Following Brownell and McInnes (1986), multi-collinearity among the eight dimensions was assessed by comparing the correlations of all twopair combinations with the overall rating. A concern arises "if the sample correlation between two of the independent variables (the dimensions of performance) is larger than the correlation of either or both with the independent variable (in this case the elicited overall rating" (p. 592). No violations were found.
} 
covariance-based SEM with LISREL 8.80 (Jöreskog \& Sörbom, 2001) to test the hypotheses. SEM was chosen over the more traditional simultaneous equations approach using regression in the path analysis for several reasons. First, Smith and Langfield-Smith (2004) suggest that SEM can filter out the measurement error better at the individual item level. This means that more precise paths can be estimated in the model. Second, it allows for more efficient use of the data relative to regression, particularly when the data set is not large as in the present study.

\section{RESULTS}

\section{Descriptive Statistics}

The means, standard deviations, theoretical ranges, and actual ranges for all variables in the study are displayed in Table I. The Pearson correlation matrix for the measured variables is given in Table II. Cronbach's (1951) alpha coefficient statistic was calculated to assess the convergent reliability of all measured variables. The alpha coefficients ranged from 0.724 to 0.892 , suggesting very acceptable levels of scale reliability. As expected, the zero-order correlations between MPERF and the two governance variables, CDCG and PDCG, are lower than the remaining correlations in Table II.

Table I: Descriptive Statistics $(n=125)$

\begin{tabular}{|l|c|c|c|c|}
\hline \multicolumn{1}{|c|}{ Variable } & Mean & Standard Deviation & Theoretical Range & Actual Range \\
\hline 1. CDCG & 3.465 & 0.995 & $1-5$ & $1-5$ \\
\hline 2. PDCG & 3.319 & 0.918 & $1-5$ \\
\hline 3. CMIND & 3.421 & 0.620 & $1-5$ & $1-5$ \\
\hline 4. MPERF & 4.946 & 1.010 & $1-7$ \\
\hline
\end{tabular}

Variable definitions: CDCG = conformance dimension of corporate governance; PDCG = performance dimension of corporate governance; CMIND = capacity for mindfulness; MPERF $=$ managerial performance.

Table II: Correlations and Reliabilities for Measured Variables $(\mathbf{n}=\mathbf{1 2 5})$

\begin{tabular}{|l|c|c|c|c|}
\hline \multicolumn{1}{|c|}{ Variable } & $\mathbf{1}$ & $\mathbf{2}$ & $\mathbf{3}$ & $\mathbf{4}$ \\
\hline 1. CDCG & $0.729^{\mathrm{a}}$ & & & \\
\hline 2. PDCG & $0.764^{* *}$ & 0.724 & & \\
\hline 3. CMIND & $0.509^{* *}$ & $0.629^{* *}$ & 0.872 & \\
\hline 4. MPERF & $0.306^{*}$ & $0.316^{*}$ & $0.392^{* *}$ & 0.892 \\
\hline
\end{tabular}

Variable definitions: $\mathrm{CDCG}=$ conformance dimension of corporate governance; PDCG = performance dimension of corporate governance; $\mathrm{CMIND}=$ capacity for mindfulness; $\mathrm{MPERF}=$ managerial performance.

${ }^{\text {a }}$ Cronbach alpha reliabilities appear in the main diagonal cells.

* (**) Significant at the 0.05 (0.01) level (two-tailed).

\section{Path Model Results}

The base model was evaluated using the chi-square test statistic, the chi-square divided by the degrees of freedom, the root mean square error of approximation (RMSEA), the goodness of fit index (GFI), the normed fit index (NFI), the non-normed fit index (NNFI), and the standardized root mean square residual (SRMR). Table III shows these results for the path model applicable to the conformance dimension and performance dimension of CG, respectively. In each case, the fit indices portray a good fit model and, hence, the model appears to fit the empirical data very well (Browne \& Cudeck, 1993; Schermelleh-Engel, Moosbrugger, \& Müller, 2003).

Table III: SEM Results for Tests of the Path Models

\begin{tabular}{lccc}
\hline Model Fit Statistics & $\begin{array}{c}\text { Path Model for Conformance } \\
\text { Dimension }\end{array}$ & $\begin{array}{c}\text { Path Model for Performance } \\
\text { Dimension }\end{array}$ & $\begin{array}{c}\text { Threshold for Good } \\
\text { (Acceptable) Fit }\end{array}$ \\
\hline$\chi^{2}$ & 148 & 148 & \\
df & 108 & 108 & $<2(3)$ \\
$\chi^{2} / \mathrm{df}$ & 137 & 137 & $<0.05(0.08)$ \\
RMSEA & 0.05 & 0.06 & $>0.95(0.90)$ \\
GFI & 0.90 & 0.90 & $>0.95(0.90)$ \\
CFI & 0.99 & 0.99 & $>0.95(0.90)$ \\
NFI & 0.96 & 0.95 & $>0.97(0.90)$ \\
NNFI & 0.98 & 0.97 & $<0.05(0.10)$ \\
SRMR & 0.06 & 0.06 & \\
\hline
\end{tabular}


Looking first at the results for the conformance dimension of CG, hypothesis H1a posits that there will not be a significant direct relationship between increased conformance and improved managerial performance, and the results shown in Figure I confirm that the path coefficient $\gamma_{1}(0.22)$ is not significant. Instead, the effect of increased conformance operates to increase mindfulness, as indicted by the significant path coefficient $\gamma_{2}(0.64)$ which, in turn, has a significant positive effective on managerial performance $\left(\gamma_{2}=0.33\right)$ thus supporting hypothesis H2a. These findings together with the correlation results provide strong support for rejecting the direct effects of increased conformance on better managerial performance; instead, more CG in the form of conformance operates indirectly by increasing mindfulness which then positively affects managerial performance.

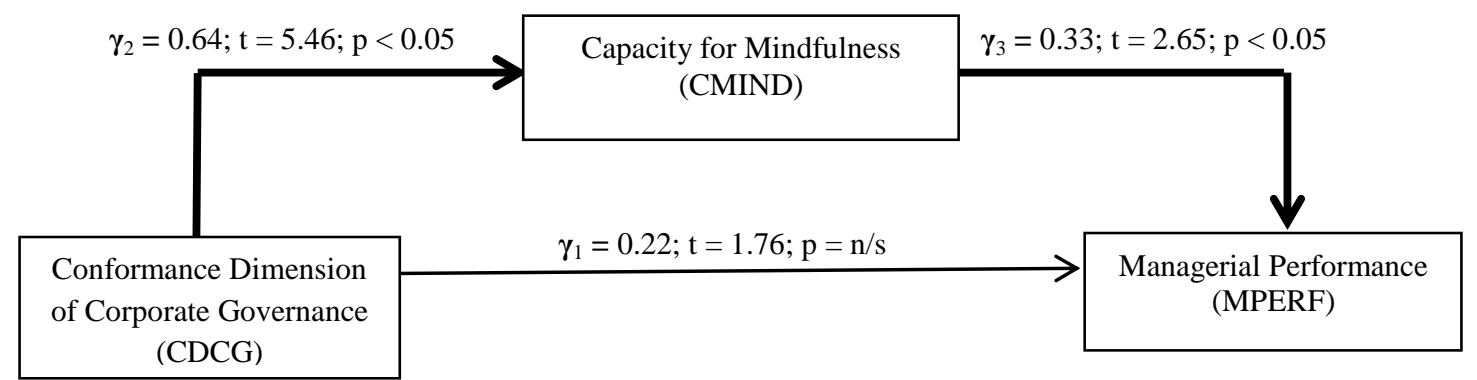

Figure I: Path Model for Conformance Dimension of Corporate Governance

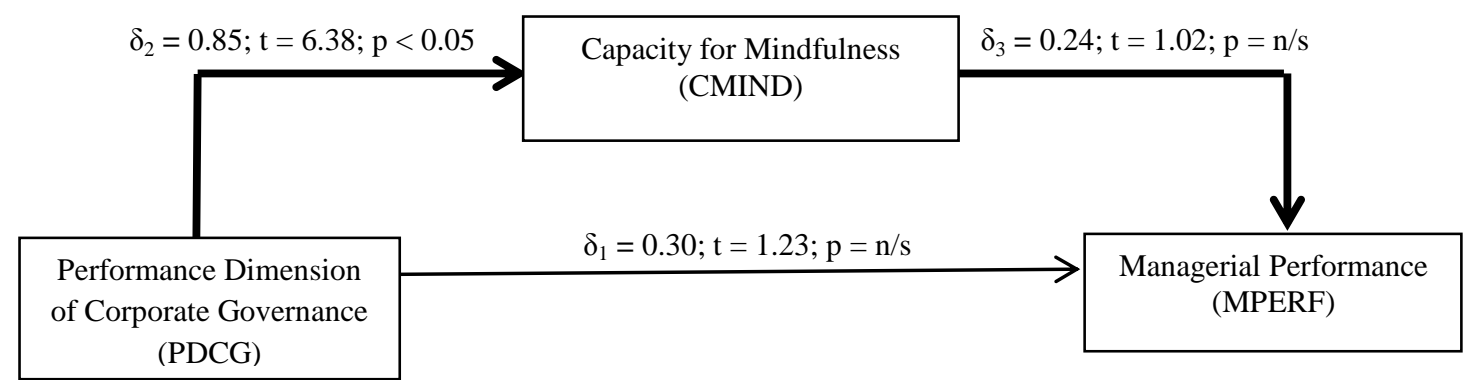

Figure II: Path Model for Performance Dimension of Corporate Governance

Turning to the results for the performance dimension of CG, hypothesis H2a predicts no direct relationship between the performance dimension and managerial performance. As indicated in Figure II, the path coefficient $\delta_{1}$ (0.30) is not significant, as expected. Hypothesis $\mathrm{H} 2 \mathrm{~b}$ instead predicts that the simple relationship between the performance dimension of and managerial performance will be explained by an indirect effect whereby CG increases the capacity for mindfulness and this, in turn, enhancing managerial performance. In fact, the path coefficient $\delta_{2}(0.85)$ is positively significant as expected; surprisingly, however, the path coefficient $\delta_{3}(0.24)$ is not significant. Therefore, there is no support for $\mathrm{H} 2 \mathrm{~b}$ and the expectation that increased performance in CG would feature indirectly in improved managerial performance must be rejected. Interestingly, this finding appears to be at odds with the significant positive correlation coefficient (0.392) between mindfulness and MPERF reported in Table II. But potentially uncovering this possibility is precisely the reason for separately analyzing the two dimensions of $\mathrm{CG}$ in the first place. For this sample, the only significant path between mindfulness and MPERF is attributable to the conformance dimension of CG and not the performance dimension. ${ }^{6}$

\section{DISCUSSION AND CONCLUSIONS}

This study sought to enhance our understanding of the process by which CG influences managerial performance, in particular, from the viewpoint of the accountant in practice. The findings suggest that the capacity

\footnotetext{
${ }^{6}$ Given the sensitivity of the managerial performance measure in the analysis, the SEM was re-run using the overall score for managerial performance as the dependent variable. A factor analysis incorporating all eight dimensions (Hall, 2008) produced a single factor with an eigenvalue of 4.46 that explained 56 percent of the total variance. The results were highly consistent with those obtained from using the original measure of managerial performance and there were no material changes in any of the path statistics, lending further support to this study's major findings.
} 
for mindfulness is an important intervening link in this process. The results provide evidence that mindfulness is significantly related to both the conformance and performance dimensions of CG as defined by the International Federation of Accountants $(2008,2009)$. This outcome is also consistent with the fundamental theoretical arguments put forth in the HRO literature, as summarized earlier, as well as the regression findings reported by Williams and Seaman (2010). As predicted in hypotheses H1a and H1b, the results did not reveal a significant direct relationship between either of the two dimensions of CG and managerial performance. This is consistent with the weight of evidence from the organizational theory literature (Daft, 1983) and most managerial accounting studies involving structural/performance effects (Shields \& Young, 1993; Luft \& Shields, 2003).

Without question, the most surprising finding is that the study failed to confirm that the performance dimension of CG, through its effect on the capacity for mindfulness, positively affects managerial performance. This is clearly revealed in the non-significant path coefficient from capacity for mindfulness to managerial performance, $\delta_{3}(0.24)$, where a significant positive relationship was anticipated. On the contrary, a strong positive relationship is found in the study between the capacity for mindfulness and managerial performance under the conformance dimension of CG. To the extent that enhanced managerial performance is positively linked to improved organizational performance, the performance dimension of CG does not appear to contribute to this objective. Nor does it appear to contribute to the balance of conformance and performance envisioned by the IFAC (2009) in its 'code of best practice' offered to the accountant in practice. Since the capacity for mindfulness is instrumental in increasing managerial performance under conditions of increasing conformance but not performance in CG, the question arises as to the cause of the latter.

To re-emphasize, according to the IFAC (2009, p.9), performance responsibilities focus on strategy, value creation, and resource utilization, challenges that the practicing accountant, especially the CFO, cannot singlehandedly control. It would seem that the CFO is just one voice among executives in the organization (including the board of directors) and, therefore, the open awareness of present moment experiences underpinning mindfulness does not translate into better performance as measured in the current study. This is consistent with Abernethy and Chua (1996, p. 573) who argue that future performance objectives are set by the "dominant organization coalition." Even more constraining is the possible violation of the controllability principle at the CFO level, meaning that for performance evaluation managers should be held accountable only for results that are within their control (Merchant, 1987; Atkinson, Kaplan, Matsumura, \& Young, 2007; Burkert, Fischer, \& Schäffer, 2011). Bearing in mind that the performance dimension of CG is essentially forward-looking, there may be little or no consensus on how to quantify robust decision-making processes, levels of risk appetite, alignment of business operations, or identifying critical points vis-à-vis changing conditions, unlike standard benchmarks that emerge for compliance. Hence, although a strong positive relationship exists between the performance dimension of CG and the capacity for mindfulness, there is no benefit transferred to improvements in managerial performance which is disappointing for those who advocate a more balanced approach to corporate governance by accountants in practice.

A further possibility underpinning the unexpected findings is that the measure of performance used in this study is simply not appropriate for capturing managerial performance at the individual level contingent on estimates of future events and outcomes at the organizational level that encompass the performance dimension of CG. Future research could possibly consider integrating more complex performance measures into this study's path model that are embedded in the performance management systems advocated by Ferreira and Otley (2009) or the diagnostic, interactive performance systems developed by Simons (1995). Finally, and perhaps most tenable, different variables may interact with or even replace the hypothesized effects of the capacity for mindfulness in the linkage to managerial performance. For instance, substantial research was carried out in managerial accounting on participative budgeting (Brownell \& McInnes, 1986; Chenhall \& Brownell, 1988; Brownell \& Dunk, 1991) which has similarities to CG systems in that they both permeate the entire organization. Many of the former research results were equivocal in that motivation, role ambiguity, job satisfaction, and even task uncertainty, were discovered to be important intervening variables influencing managerial performance at the individual level. Future research on the performance dimension of $\mathrm{CG}$ could give consideration to these variables.

Several limitations of this study are worth noting, including common-method bias from self-reported data (Kren, 1992), which could bias the model relationships, and the inability to ascertain nonresponse bias as a result of obtaining survey data from the Internet. It also needs to be stressed that path analysis does not mean 'causal 
analysis' (Chenhall \& Brownell, 1988) and, thus, the results need to be interpreted within the theoretical arguments. As acknowledged earlier, the performance measure used in this study may be inappropriate but in a sense, this raises concerns about the validity of the controllability principle (Merchant \& Otley, 2006; Merchant \& Van der Stede, 2007) which is a cornerstone of managerial accounting. Future research should re-address alternative measures of managerial performance as well as additional intervening links between the two dimensions of CG that may indirectly influence managerial performance. These limitations notwithstanding, the findings of this study indicate that achieving a balance between the conformance and performance dimensions of governance may have differential effects on managerial performance for the accountant in practice. The onus may rest with the initiative of organizations to crystalize the role of the accountant in CG, especially the CFO, in matters of strategy, management of risks, and the responsible use of resources as these relate to managerial performance and the larger objective of effective organizational performance.

\section{AUTHOR INFORMATION}

Dr. Williams has been a Professor of Accounting at the University of Alberta, Canada; University of Nairobi, Kenya; Queen's University, Canada; Nanyang Technological University, Singapore; and is currently a Practice Associate Professor in the School of Accountancy, Singapore Management University, Singapore. He has consulted internationally and conducted extensive research on management accounting control systems, with publications in Accounting, Organizations and Society, Behavioral Research in Accounting, California Management Review, Contemporary Accounting Research, Journal of Accounting Historians, Journal of Applied Business Research, Management Accounting Research, and Review of Business Information Systems. E-mail: jiwilliams@smu.edu.sg

Dr. Seaman is a Professor of Accounting at The Business School, Humber Institute of Technology \& Advanced Learning. He has several years of professional experience providing accounting and consulting services to private and public organizations. His research has investigated organization strategy, structure and process as they relate to management accounting and control systems. Currently, Dr Seaman is conducting research in Canadian organizations with the focus being governance, ethics, and management accounting systems and their relationship to the set of cognitive high reliability characteristics. E-mail: alfred.seaman@ humber.ca (Corresponding author)

\section{REFERENCES}

1. Abernethy, M. A., \& Chua, W. F. (1996). A field study of control system 'redesign': The impact of institutional process on strategic choice. Contemporary Accounting Research, 13, 569-606.

2. Ahmed, K., Hossain, M., \& Adams, M. B. (2006). The effects of board composition and board size on the informativeness of annual accounting earnings. Corporate Governance: An International Review, 14, 418431.

3. Ahrens, T., Filatotchev, I., \& Thomsen, S. (2011). The research frontier in corporate governance. Journal of Management and Governance, 15, 311-325.

4. Armstrong, J. S., \& Overton, T. S. (1997). Estimating nonresponse bias in mail surveys. Journal of Marketing Research, 14, 396-402.

5. Atkinson, A. A., Kaplan, R. S., Matsumura, E. M., \& Young, S. M. (2007). Management accounting (5 ${ }^{\text {th }}$ ed.). Upper Saddle River: Prentice Hall.

6. Beekes, W., \& Brown, P. (2006). Do better-governed Australian firms make more informative disclosures? Journal of Business Finance and Accounting, 33, 422-450.

7. Bierly, P. E., \& Spender, J. C. (1995). Culture and high reliability organizations: The case of the nuclear submarine. Journal of Management, 21, 639-656.

8. Browne, M. W., \& Cudeck, R. (1993). Alternative ways of assessing model fit. In K. Bollen \& J. S. Long (Eds.), Testing structural equation models (pp. 136-162). Newbury Park: Sage Publications, Inc.

9. Brownell, P., \& McInnes, M. (1986). Budgetary participation, motivation, and managerial performance. The Accounting Review, 61, 587-600.

10. Burkert, M., Fischer, F. M., \& Schäffer, U. (2011). Application of the controllability principle and managerial performance: The role of role perceptions. Management Accounting Research, 22, 143-159.

11. Bushman, R., \& Smith, A. (2001). Financial accounting information and corporate governance. Journal of Accounting and Economics, 32, 237-334. 
12. Business Sector Advisory Group on Corporate Governance. (1998). Corporate governance: Improving competitiveness and access to capital in global markets. Paris, France: Organization for Economic Cooperation and Development.

13. Brown, P., Beekes, W., \& Verhoeven, P. (2011). Corporate governance, accounting and finance: A review. Accounting and Finance, 51, 96-172.

14. Burns, T., \& Stalker, G. M. (1961). The management of innovation. London: Tavistock.

15. Byard, D., Li, Y., \& Weintrop, J. (2006). Corporate governance and the quality of financial analysts' information. Journal of Accounting and Public Policy, 25, 609-625.

16. Cadbury, A. Sir. (1992). Report of the committee on the financial aspects of corporate governance. The London Stock Exchange, Financial Reporting Council, Accountancy Profession, London, UK.

17. Chong, V. K., \& Chong, K. M. (2002). Budget goal commitment and informational effects of budget participation on performance: A structural equation modeling approach. Behavioral Research in Accounting, 14, 65-84.

18. Cronbach, L. J. (1951). Coefficient alpha and the internal structure of tests. Psychometrika, 16, 297-334.

19. Daft, R. L. (1983). Organizational theory and design. St. Paul, MN: West Publishing.

20. Durisin, B., \& Puzone, F. (2009). Maturation of corporate governance research, 1993-2007: An assessment. Corporate Governance, An International Review, 17, 266-291.

21. Financial Reporting Council. (2010). The UK Corporate Governance Code. London, UK.

22. Galbraith, J. (1973). Designing complex organizations. Reading, MA: Addison-Wesley.

23. Govindarajin, V. (1986). Impact of participation in the budgetary process on managerial attitudes and performance: Universalistic and contingency perspectives. Decision Sciences, 17, 496-516.

24. Henman, L. D. (2013). A CFO's guide to corporate governance. Henman Performance Group. Retrieved from www.henmanperformancegroup.com

25. Hall, M. (2008). The effect of comprehensive performance measurement systems on role clarity, psychological empowerment and managerial performance. Accounting, Organizations and Society, 33, 141-163.

26. Hopwood, A. (1976). Accounting and human behavior. Englewood Cliffs, NJ: Prentice-Hall.

27. Huse, M., Hoskisson, R., Zattoni, A., \& Viganò, R. (2011). New perspectives on board research: Changing the agenda. Journal of Management and Governance, 15, 5-28.

28. International Federation of Accountants. (2009). International good practice guidance: Evaluating and improving governance in organizations. New York.

29. International Federation of Accountants. (2008). Financial reporting supply chain: Current perspectives and directions. New York.

30. International Federation of Accountants. (2005). The roles and domain of the professional accountant in business. New York.

31. International Federation of Accountants and Chartered Institute of Management Accountants. (2004). Enterprise governance: Getting the balance right. New York.

32. Jöreskog, K. G., \& Sörbom, D. (2001). LISREL 8: User's reference guide (2 ${ }^{\text {nd }}$ ed.). Lincolnwood: Scientific Software International.

33. Kim, J. B., \& Yi, C. H. (2006). Ownership structure, business group affiliation, listing status, and earnings management: Evidence from Korea. Contemporary Accounting Research, 23, 427-464.

34. Kim J. B., \& Yi, C. H. (2009). Does auditor designation by the regulatory authority improve audit quality? Evidence from Korea. Journal of Accounting and Public Policy, 28, 207-230.

35. Kren, L. (1992). Budgetary participation and managerial performance: The impact of information and environmental volatility. The Accounting Review, 67, 511-526.

36. Langer, E. J. (1997). The power of mindful learning. Reading, MA: Addison-Wesley.

37. Langer, E. J. (1989). Minding matters: The consequences of mindlessness-mindfulness. In L. Berkowitz (Ed.), Advances in experimental social psychology (Vol. 22, pp. 137-173). San Diego, CA: Academic Press.

38. Lawrence, P. R., \& Lorsch, J. W. (1967). Organization and Environment. Cambridge, MA: Harvard University.

39. Luft, J., \& Shields, M. D. (2003). Mapping management accounting: Graphics and guidelines for theoryconsistent empirical research. Accounting, Organizations and Society, 28, 169-249. 
40. Mahoney, T. A., Jerdee, T. H., \& Carroll, S. J. (1965). The jobs of management. Industrial Relations, February, 97-110.

41. Mahoney, T. A., Jerdee, T. H., \& Carroll, S. J. (1963). Development of managerial performance: A research approach. New York: Southwestern Publishing Company.

42. March, J. G., Sproull, L. S., \& Tamuz, M. (1991). Learning from samples of one or fewer. Organization Science, 2, 1-13.

43. Merchant, K. A. (1987). How and why firms disregard the controllability principle. In W. J. Bruns \& R. S. Kaplan (Eds.), Accounting and management: Field study perspectives (pp. 316-338). Boston: Harvard Business School.

44. Merchant, K. A. (1981). The design of the corporate budgeting system: Influences on managerial behavior and performance. The Accounting Review, 56, 813-829.

45. Milani, K. W. (1975). The relationship of participation in budget setting to industrial supervisor performance and attitudes: A field study. The Accounting Review, 47, 274-284.

46. McNulty, T., Zattoni, A., \& Douglas, T. (2013). Developing corporate governance research through qualitative methods: A review of previous studies. Corporate Governance: An International Review, 21(2), 183-198.

47. Nunnally, J. C. (1967). Psychometric theory. New York: McGraw Hill.

48. Otley, D. (1999). Performance management: A framework for management control systems research. Management Accounting Research, 10(4), 363-382.

49. Otley, D., \& Pollanen, R. M. (2000). Budgetary criteria in performance evaluation: A critical appraisal using new evidence. Accounting, Organizations and Society, 25, 483-496.

50. Parker, R. J., \& Kyj, L. (2006). Vertical information sharing in the budgeting process. Accounting, Organizations and Society, 31, 27-45.

51. Perrin, C. (1995). Organizations as contexts: Implications for safety science and practice. Industrial and Environmental Crisis Quarterly, 4, 152-174.

52. Perrow, C. (1970). Organizational analysis: A sociological review. Belmont, CA: Wadsworth Publishing.

53. Pricewaterhousecoopers. (2012). Corporate governance. Retrieved from www.pwc.com

54. $\quad$ Pricewaterhousecoopers. (2008). Todays challenges. Retrieved from www.pwc.com

55. Rochlin, G. I. (1993). Defining 'high reliability' organizations in practice: A taxonomy prologue. In K. H. Roberts (Ed.), New challenges to understanding organizations (pp. 11-32). New York: Free Press.

56. Rochlin, G. I. (1989). Informal organizational networking as a crisis avoidance strategy: U.S. naval flight operations as a case study. Industrial Crisis Quarterly, 3, 11-32.

57. Roth, G. (1997). Analysis of decision making in nuclear power plant emergencies: An investigation of aided decision making. In C. Zsambok \& G. Klein (Eds.), Naturalistic decision making (pp. 175-182). Mahwah, NJ: Erlbaum.

58. Schermelleh-Engel, K., Moosbrugger, H., \& Müller, H. (2003). Evaluating the fit of structural equation models: Tests of significance and descriptive goodness-of-fit measures. Methods in Psychological Research, 8, 23-74.

59. Schuman, P. R. (1993). The negotiated order of organizational reliability. Administration and Society, 25, 353-372.

60. Scott, K. E. (1999). Corporate governance and east Asia 2. (Working Paper No. 176). John M. Olin Program in Law and Economics, Stanford Law School, CA, USA.

61. Segal, J. (2002). The role of the CFO in corporate governance. Australian Securities \& Investments Commission, Sydney, pp. 1-14.

62. Shields, M., \& Young, S. M. (1993). Antecedents and consequences of participative budgeting: Evidence on the effects of asymmetrical information. Journal of Management Accounting Research, 10, 265-280.

63. Shleifer, A., \& Vishny, R. (1997). A survey of corporate governance. Journal of Finance, 52(2), 737-783.

64. Sitkin, S. B. (1992). Learning through failure: The strategy of small losses. In B. M. Staw \& L. L. Cummings (Eds.), Research in organizational behaviour (Vol. 14, pp. 231-266). Greenwich, CT: JAI Press.

65. Sloan, R. G. (2001). Financial accounting and corporate governance: A discussion. (Working paper). School of Business Administration, University of Michigan, USA, pp, 1-23.

66. Smith, D., \& Langfield-Smith, K. (2004). Structural equation modeling in management accounting research: Critical analysis and opportunities. Journal of Accounting Literature, 23, 49-86. 
67. Starbuck, W. H., Greve, A., \& Hedberg, B. L. T. (1978). Responding to crisis: Theory and the experience of European business. In C. F. Smart \& W. T. Stanbury (Eds.), Studies in crises management (pp. 107134). Toronto: Butterworth.

68. Steers, R. M. (1976). Factors affecting job attitudes in a goal-setting environment. Academy of Management Journal, 19, 6-16.

69. Tamuz, M. (1994). Developing organizational safety information systems for monitoring potential dangers. In G. E. Apostolakis \& T. S. White (Eds), Proceddings of PSAM II, 2 (pp. 7-12), University of California, Los Angeles.

70. Tessier, S., \& Otley, D. (2012). A conceptual development of Simon's levers of control framework. Management Accounting Research, 3, 171-185.

71. Tymon, W. G. Jr., Stout, D. E., \& Shaw, K. N. (1998). Critical analysis and recommendations regarding the role of perceived environmental uncertainty in behavioral accounting research. Behavioral Research in Accounting, 10, 23-46.

72. Watts, R. L. (2003). Conservatism in accounting part I: Explanations and implications. Accounting Horizons, 17, 207-221.

73. Weick, K. E. (1979). The social psychology of organizing. Reading, MA: Addison-Wesley.

74. Weick, K. E. (1990). The vulnerable system: An analysis of the Tenerife air disaster. Journal of Management, 16, 571-593.

75. Weick, K. E. (1993). The collapse of sensemaking in organizations: The Mann Gulch disaster. Administrative Science Quarterly, 38, 628-652.

76. Weick, K. E., \& Sutcliffe, K. M. (2001). Managing the unexpected. San Francisco, CA: Jossey-Bass.

77. Weick, K. E., Sutcliffe, K. M., \& Obstfeld, D. (1999). Organizing for high reliability: Processes of collective mindfulness. Research in Organizational Behaviour, 21, 81-123.

78. Westrum, R. (1992). Cultures with requisite imagination. In J. A. Wise, D. Hopkin, \& P. Stager (Eds), Human factors in safety critical systems (pp. 401-416). Berlin: Springer-Verlag.

79. Wildavsky, A. (1991). Searching for safety. New Brunswick: Transaction Books.

80. Williams, J. J., \& Seaman, A. E. (2010). Corporate governance and mindfulness: The impact of management accounting systems change. The Journal of Applied Business Research, 26(5), 1-17. 


\section{NOTES}

